\title{
INDUKSI OVULASI DAN PEMIJAHAN IKAN AGAMYSIS (Agamyxis albomaculatus) MENGGUNAKAN HORMON YANG BERBEDA
}

\author{
Bastiar Nur", Asep Permana, Agus Priyadi, Siti Zuhriyah Mustofa, dan Siti Murniasih \\ Balai Riset Budidaya Ikan Hias
}

(Naskah diterima: 23 November 2016; Revisi final: 24 Juli 2017; Disetujui publikasi: 24 Juli 2017)

\begin{abstract}
ABSTRAK
Ikan agamysis (Agamyxis albomaculatus) merupakan ikan hias air tawar introduksi yang memiliki potensi cukup bagus untuk dikembangkan di Indonesia, namun masih bermasalah dalam budidayanya. Penelitian ini bertujuan untuk menguji efektivitas kombinasi hormon berbeda dalam menginduksi ovulasi dan pemijahan ikan agamysis. Jumlah ikan yang digunakan sebanyak 30 ekor (15 jantan dan 15 betina) dengan ukuran panjang 10-15 cm dan bobot 50-200 g. Ikan uji dipelihara dalam akuarium sistem resirkulasi dan diberi pakan cacing tanah dua kali sehari secara ad libitum. Perlakuan yang diberikan berupa penggunaan beberapa jenis hormon yaitu: (A) LHRHa dan antidopamin (ovaprim) dosis $0,7 \mathrm{~mL} / \mathrm{kg}$; (B) human chorionic gonadotropin (hCG) dosis 500 IU/kg; (C) aromatase inhibitor (Al) dosis 10 mg/kg; (D) kombinasi Al dosis $10 \mathrm{mg} /$ $\mathrm{kg}+$ ovaprim dosis $0,7 \mathrm{~mL} / \mathrm{kg}$; serta (E) kombinasi $\mathrm{hCG}$ dosis $500 \mathrm{IU} / \mathrm{kg}+$ ovaprim dosis $0,7 \mathrm{mg} / \mathrm{kg}$. Hormon diberikan melalui penyuntikan secara intramuskuler. Hasil penelitian menunjukkan bahwa penggunaan kombinasi hormon $\mathrm{hCG}$ dosis $500 \mathrm{IU} / \mathrm{kg}+$ ovaprim dosis $0,7 \mathrm{~mL} / \mathrm{kg}$; memberikan respons pemijahan terbaik dengan waktu laten 7-12 jam; bobot telur ovulasi 7,3-9,4 g; derajat pembuahan 5,71\% $34,7 \%$ dan derajat penetasan $32,5 \% 50,44 \%$ Penggunaan kombinasi hormon hCG dan ovaprim efektif menstimulasi proses ovulasi telur sehingga dapat menjadi acuan untuk peningkatan produksi larva ikan agamysis dalam pemijahan buatan.
\end{abstract}

\section{KATA KUNCl: Agamyxis albomaculatus; pemijahan; hormonal \\ ABSTRACT: Induced ovulation and spawning of agamysis (Agamyxis albomaculatus) using different hormones. By: Bastiar Nur, Asep Permana, Agus Priyadi, Siti Zuhriyyah Musthofa, and Siti Murniasih}

\begin{abstract}
Agamysis (Agamyxis albomaculatus) is an introduced freshwater fish that has the potential to be developed in Indonesia. Yet, thefish has not been successfully cultivated. This research was conducted to determinethe effectiveness of different hormone combinations to induce ovulation and spawning of agamysis. This research used 30 fishes (15 male and 15 female) ranged $10-15 \mathrm{~cm}$ in length and $50-200 \mathrm{~g}$ in body weight. The fish were stocked in aquaria equipped with recirculation system and fed with earthworm by ad libitum twice a day. Thetreatments were: (A) LHRHa and antidopamin (ovaprim) dose of $0.7 \mathrm{~mL} / \mathrm{kg}$, (B) human chorionic gonadotropin (hCG) dose of $500 \mathrm{lU} / \mathrm{kg}$, (C) aromatase inhibitor (Al) dose of $10 \mathrm{mg} / \mathrm{kg}$, (D) a combination of Al dose of $10 \mathrm{mg} / \mathrm{kg}+$ ovaprim dose of $0.7 \mathrm{~mL} / \mathrm{kg}$, and $(E)$ a combination of hCG dose of $500 \mathrm{IU} / \mathrm{kg}+$ ovaprim dose of $0.7 \mathrm{mg} / \mathrm{kg}$. The hormones were given through intramuscularly injection. The results showed that the combination of ovaprim dose of $0.7 \mathrm{~mL} / \mathrm{kg}$ and hCG dose of 500 IU/kg produced the best spawning response, with the latent period of 7-12 hours, weight of ovulated eggs of 7.3-9.4 g, fertilization rate of $5.71 \%$ to $34.7 \%$ and hatching rate between $32.5 \%$ - 50.44\% In conclusion, the combination of hCG and ovaprim was found to be more effective to stimulate egg ovulation of agamysis and could be used in improving larvae production.
\end{abstract}

KEYWORDS: Agamyxis albomaculatus, spawning, hormonal

\section{PENDAHULUAN}

Spotted talking catfish atau spotted Raphael catfish merupakan nama umum dari ikan Agamyxis

\# Korespondensi: Balai Riset Budidaya Ikan Hias. Jl. Perikanan No. 13, Pancoran Mas, Depok 16436, Indonesia.

Tel. + (021) 7520482

E-mail: bastiarnurdin@gmail.com albomaculatus. Para praktisi ikan hias di Indonesia lebih mengenalnya sebagai ikan agamysis. Ikan demersal ini merupakan ikan introduksi dari delta Sungai Amazon (Luna et al., 2014) yang sudah mulai dikembangkan oleh pembudidaya ikan hias di beberapa daerah di Indonesia khususnya wilayah Jabo detabek. Hasil survai ke salah satu eksportir ikan hias (Kampung Ikan, 
Bekasi) pada tahun 2015 diketahui bahwa ikan agamysis pada ukuran 1 inci dijual dengan harga Rp 2.500,00 per ekor dengan rata-rata kebutuhan untuk permintaan ekspor sebesar 10.000 ekor untuk setiap bulannya. Namun demikian, produksi ikan agamysis di tingkat pembudidaya belum mampu memenuhi kebutuhan tersebut. Berdasarkan hasil survai ke beberapa pembudidaya lokal, didapatkan informasi bahwa permasalahan yang dihadapi dalam usaha budidaya ikan agamysis adalah rendahnya jumlah larva yang dihasilkan. Hal ini diduga berkaitan dengan rendahnya daya tetas telur $(5 \% 10 \%$, serta tingkat sintasan larvanya yang juga rendah (sekitar 50\% dalam satu siklus pemijahan. Hal ini juga berkaitan dengan kualitas induk khususnya kualitas telur yang dihasilkan selama proses pematangan gonad.

Peningkatan kualitas telur dapat dilakukan melalui pemberian pakan yang memiliki nilai nutrisi yang cukup. Salah satu bentuk perbaikan kualitas pakan dengan tujuan peningkatan kualitas telur ikan adalah dengan penambahan vitamin $\mathrm{E}$ dal am pakan (Yulfiperius et al., 2003) yang juga dilakukan pada ikan agamysis; dan merupakan tahapan awal dari kegiatan manipulasi hormon untuk ovulasi dan pemijahan ini. Kegiatan ini merupakan satu rangkaian yang tidak terpisahkan yang dimulai dari pematangan gonad, induksi ovulasi dan pemijahan; hingga penanganan telur dan larva melalui pendekatan lingkungan.

Ovulasi merupakan proses keluarnya telur ke rongga ovari atau rongga perut setelah pecahnya folikel oosit, dan pemijahan merupakan proses keluarnya telur dari dalam tubuh induk (rongga ovari) ke lingkungan. Dalam habitat alaminya, ovulasi dan pemijahan ikan akan terjadi secara alami setelah adanya stimulasi yang berasal dari faktor lingkungan seperti suhu, fotoperiode, salinitas, pasang surut, dan beberapa faktor lainnya (Keys \& Crocos, 2006; Mylonas et al., 2010). Namun dalam lingkungan budidaya, beberapa faktor lingkungan hilang yang menyebabkan kegagalan ovulasi dan pemijahan ikan. Oleh karena itu, penggunaan hormon eksogen merupakan salah satu cara yang efektif untuk merangsang pemijahan pada ikan (Mylonas et al., 2010). Beberapa jenis hormon dan bahan kimia lain yang umum digunakan untuk menginduksi ovulasi dan pemijahan ikan adalah hormon gonadotropin releasing hormon analog dari ikan salmon (sGnRHa) dengan penambahan antidopamin atau lebih dikenal dengan ovaprim, human chorionic gonadotropin (hCG), aromatase inhibitor (AI), dan antidopamin (AD) dan beberapa hormon lainnya. Penggunaan ovaprim telah berhasil menginduksi ovulasi dan pemijahan ikan botia (Legendre et al., 2012), ikan lele (Iswanto et al., 2014), dan beberapa spesies ikan Cyprinidae seperti ikan koi dan mas koki (Yanong et al., 2015). Penggunaan aromatase inhibitor juga dapat memicu terjadinya ovulasi pada ikan patin (Pangasianodon hypophthalmus) (Mahdaliana, 2014), lele dumbo (Clarias sp.) (Sumantri, 2006) dan ikan Sumatera (Puntius tetrazona) (Hakim, 2010). Umumnya, penggunaan ovaprim dalam aplikasinya untuk menginduksi ovulasi dan pemijahan dikombinasikan dengan bahan maupun hormon lain seperti aromatase inhibitor (Al) untuk merangsang pemijahan ikan Sumatera (Puntius tertrazona) (Hakim, 2010); dengan Prostaglandin-F2á (PGF2á) untuk menginduksi ovulasi dan pemijahan ikan motan (Thynnicthys thynnoides Blkr) (Sukendi et al., 2010); atau dengan hCG untuk merangsang ovulasi ikan Tor soro (Farastuti, 2014). Oleh karena itu, penelitian ini bertujuan untuk menentukan kombinasi hormon yang efektif dalam induksi ovulasi dan pemijahan ikan agamysis.

\section{BAHAN DAN METODE}

Ikan uji yang digunakan sebanyak 30 ekor (15 jantan dan 15 betina) dengan kisaran panjang 10-15 cm dan bobot badan 50-200 g per ekor dengan umur minimal satu tahun dan telah matang gonad. Ikan matang gonad ditandai dengan bentuk perut yang besar membulat dan ketika dilakukan penekanan terasa lembek (TKG IV) untuk ikan betina dan menghasilkan sperma untuk ikan jantan.

Ikan uji dipelihara dalam akuarium resirkulasi sebanyak lima buah dengan kepadatan enam ekor per akuarium (tiga jantan + tiga betina) dan diberi pakan cacing tanah dua kali sehari secara ad libitum. Hormon induksi ovulasi sebagai perlakuan dalam penelitian ini adalah: ovaprim, human chorionic gonadotropin (hCG), aromatase inhibitor (Al) jenis Imidazole, kombinasi antara Al dan ovaprim, serta hCG dan ovaprim yang diuji masing-masing pada tiga ekor induk betina dengan dosis dan jumlah penyuntikan sebagaimana disajikan pada Tabel 1. Induk jantan disuntik menggunakan ovaprim sebanyak $0,7 \mathrm{~mL}$ dengan satu kali penyuntikan. Hormon diberikan melalui penyuntikan (injeksi) secara intramuskular pada bagian punggung ikan.

Pengalinan (stripping) ikan uji betina yang telah diinduksi hormon dilakukan 6-7 jam setelah penyuntikan akhir. Induk yang belum berhasil mengeluarkan telur pada perco baan stripping pertama dikembalikan ke wadah pemeliharaan semula dan dilakukan percobaan stripping berikutnya setiap jam hingga telurnya bisa dikeluarkan. Setelah telur berhasil dikeluarkan, pengalinan induk jantan dilakukan untuk mengeluarkan spermanya. Sperma yang didapatkan dari tiga ekor induk jantan pada setiap perlakuan 
Tabel 1. Jenis hormon, dosis, jumlah, dan durasi penyuntikan hormon pada induk ikan betina

Table 1. Types, dosages, quantities, and durations of injected hormones to the female broodstock

\begin{tabular}{cccc}
\hline $\begin{array}{c}\text { Perlakuan } \\
\text { Treatments }\end{array}$ & $\begin{array}{c}\text { Dosis.kg } \\
\text { Dosage.kg- }^{-1}\end{array}$ & $\begin{array}{c}\text { Jumlah penyuntikan (kali) } \\
\text { Number of injections (times) }\end{array}$ & $\begin{array}{c}\text { Durasi (jam) } \\
\text { Duration (hours) }\end{array}$ \\
\hline A & Ovaprim $0.7 \mathrm{~mL}$ & 1 & - \\
B & hCG $500 \mathrm{IU}$ & 1 & - \\
C & Al $10 \mathrm{mg}$ & 1 & - \\
D & Al $10 \mathrm{mg}+$ ovaprim $0.7 \mathrm{~mL}$ & 2 & 7 \\
E & hCG 500 IU + ovaprim $0.7 \mathrm{~mL}$ & 2 & 7 \\
\hline
\end{tabular}

Keterangan (Note):

- Durasi ialah jarak waktu antara penyuntikan hormon I dan II untuk perlakuan jenis hormon yang kombinasi (perlakuan D dan E) yaitu selama tujuh jam berdasarkan Adi (1999) pada ikan baung (Duration is the interval of the first injection to the second injection on combination hormone treatments ( $D$ and E). Injection interval was seven hour following Adi (1999) for catfish)

- Pada perlakuan D hormon yang diinjeksi pertamayaitu Al kemudian yang kedua ovaprim, sedangkan pada perlakuan E yang pertama hCG kemudian ovaprim (The first injection used AI (D) and HCG (E) and second was ovaprime for each treatment)

disatukan untuk membuahi telur dari tiga ekor induk betina. Selanjutnya dilakukan pencampuran sperma dan telur untuk pembuahan buatan. Telur yang telah dibuahi kemudian diinkubasi menggunakan wadah akuarium sistem air tenang (stagnan) dengan ketinggian air 15 $\mathrm{cm}$. Air media inkubasi diberi methylen blue dengan dosis $0,1 \mathrm{mg} / \mathrm{L}$ dan diaerasi.

\section{Parameter Uji}

Parameter yang diamati pada penelitian ini terdiri atas: waktu laten (jam) yaitu waktu yang dibutuhkan ikan sampai telur ovulasi dan memijah dihitung dari waktu penyuntikan terakhir; bobot telur ovulasi (g) yaitu bobot telur total yang keluar pada saat memijah; jumlah telur ovulasi (butir) yaitu jumlah telur total yang keluar pada saat memijah yang didapatkan dengan membandingkan antara bobot total telur yang dikeluarkan dibagi dengan bobot satu butir telur; diameter telur diukur menggunakan bantuan mikroskop okuler perbesaran 40x dan kemudian dihitung kisaran diameter telur rata-ratanya. Jumlah sampel telur yang digunakan sebanyak 100 butir. Parameter derajat pembuahan (DB) ditentukan dari jumlah telur yang terbuahi dibagi dengan jumlah total telur dan dinyatakan dalam persen yang diamati 7-8 jam setelah pembuahan (Arfah et al., 2006). Telur yang telah dibuahi berwarna kuning mengilap, sedangkan telur yang tidak dibuahi berwarna putih keruh. Derajat pembuahan (DB) telur dihitung berdasarkan rumus Effendie (1997):

$$
\mathrm{DB}=\frac{\text { Jumlah telur yang terbuahi (butir) }}{\text { Jumlah total telur (butir) }} \times 100
$$

Derajat penetasan (DT), ditentukan dari jumlah telur yang menetas dibagi dengan total telur yang terbuahi dan dinyatakan dalam persen. Derajat penetasan dapat dihitung dengan menggunakan rumus sebagai berikut:

$$
\text { DT }=\frac{\text { Jumlah telur yang menetas (butir) }}{\text { Jumlah telur yang terbuahi (butir) }} \times 100
$$

\section{Analisis Data}

Data pemijahan (waktu laten, bobot telur, jumlah telur, diameter telur, DB, dan DT) dianalisis secara deskriptif.

\section{HASIL DAN BAHASAN}

Penggunaan kombinasi hormon hCG dosis 500 IU/ $\mathrm{kg}$ dan ovaprim dosis $0,7 \mathrm{~mL} / \mathrm{kg}$ dalam menginduksi ovulasi dan pemijahan ikan agamysis memberikan respons pemijahan lebih baik dibandingkan perlakuan lainnya, baik dengan menggunakan kombinasi Al dan ovaprim maupun hormon tunggal ovaprim, hCG, dan Al. Kombinasi hormon hCG dosis $500 \mathrm{IU} / \mathrm{kg}$ dan ovaprim dosis $0,7 \mathrm{~mL} / \mathrm{kg}$ dapat mempercepat proses ovulasi (waktu laten lebih singkat) dan menghasilkan telur dengan daya tetas telur yang relatif lebih tinggi. Data hasil pengamatan waktu laten dan jumlah telur ovulasi ikan agamysis disajikan pada Tabel 2.

Berdasarkan data hasil penyuntikan ikan agamysis menggunakan kombinasi hormon hCG 500 IU dengan ovaprim $0,7 \mathrm{~mL} / \mathrm{kg}$ bobot badan untuk menginduksi ovulasi dan pemijahan ikan agamysis, waktu yang 
Tabel 2. Waktu laten dan jumlah telur yang dihasilkan induk ikan agamysis dengan penyuntikan hormon ovulasi yang berbeda

Table 2. Latency time and the number of eggs produced by agamysis injected with different ovulation hormones

\begin{tabular}{|c|c|c|c|}
\hline $\begin{array}{l}\text { Perlakuan } \\
\text { Treatments }\end{array}$ & $\begin{array}{l}\text { Bobot induk } \\
\text { Body weight (g) }\end{array}$ & $\begin{array}{l}\text { Waktu laten (jam) } \\
\text { Latency time (hours) }\end{array}$ & $\begin{array}{l}\text { Jumlah telur ovulasi (butir) } \\
\text { Number of eggs (eggs) }\end{array}$ \\
\hline \multirow{3}{*}{ Ovaprim $0,7 \mathrm{~mL} \cdot \mathrm{kg}^{-1}$} & 135,00 & $9.04^{\prime}$ & 3.23 \\
\hline & 85,50 & $11.52^{\prime}$ & 2.09 \\
\hline & 52,21 & $18.03^{\prime}$ & 1.444 \\
\hline \multicolumn{2}{|c|}{ Rerata (Average) } & $12.59^{\prime} \pm 4.34^{\prime}$ & $2.254 \pm 904$ \\
\hline \multirow{3}{*}{ hCG 500 IU...kg ${ }^{-1}$} & 50,00 & $\begin{array}{l}\text { Tidak ovulasi } \\
\text { Not ovulated }\end{array}$ & - \\
\hline & 90,00 & $\begin{array}{l}\text { Tidak ovulasi } \\
\text { Not ovulated }\end{array}$ & - \\
\hline & 84,82 & $\begin{array}{l}\text { Tidak ovulasi } \\
\text { Not ovulated }\end{array}$ & - \\
\hline \multicolumn{2}{|c|}{ Rerata (Average) } & - & - \\
\hline \multirow{3}{*}{ Al $10 \mathrm{mg} \cdot \mathrm{kg}^{-1}$} & 50,35 & $\begin{array}{l}\text { Tidak ovulasi } \\
\text { Not ovulated }\end{array}$ & - \\
\hline & 75,60 & $\begin{array}{l}\text { Tidak ovulasi } \\
\text { Not ovulated }\end{array}$ & - \\
\hline & 80,85 & $\begin{array}{l}\text { Tidak ovulasi } \\
\text { Not ovulated }\end{array}$ & - \\
\hline \multicolumn{2}{|c|}{ Rerata (Average) } & - & - \\
\hline \multirow{3}{*}{$\begin{array}{l}\text { Al } 10 \mathrm{mg}+ \\
\text { ovaprim } 0,7{\mathrm{~mL} . \mathrm{kg}^{-1}}^{-1}\end{array}$} & 89,50 & $14.00^{\prime}$ & 2.835 \\
\hline & 200,00 & $16.00^{\prime}$ & 5.594 \\
\hline & 55,20 & $\begin{array}{l}\text { Tidak ovulasi } \\
\text { Not ovulated }\end{array}$ & - \\
\hline \multicolumn{2}{|c|}{ Rerata (Average) } & $15.00^{\prime} \pm 1.0^{\prime}$ & $4.215 \pm 1.951$ \\
\hline \multirow{3}{*}{$\begin{array}{l}\text { hCG } 500 \mathrm{IU}+ \\
\text { ovaprim } 0,7 \mathrm{~mL} . \mathrm{kg}^{-1}\end{array}$} & 68,25 & $7.00^{\prime}$ & 2.774 \\
\hline & 160,00 & $12.00^{\prime}$ & 3.04 \\
\hline & 175,20 & $11.30^{\prime}$ & 3.572 \\
\hline \multicolumn{2}{|c|}{ Rerata (Average) } & $10.10^{\prime} \pm 2.45^{\prime}$ & $3.128 \pm 406$ \\
\hline
\end{tabular}

dibutuhkan untuk berlangsungnya pemijahan (keluarnya telur saat pengalinan) atau waktu laten lebih cepat (10 jam 10 menit) dibandingkan dengan perlakuan Al $10 \mathrm{mg}$ dan ovaprim $0,7 \mathrm{~mL} / \mathrm{kg}$ bobot badan (15 jam) maupun penyuntikan tunggal ovaprim $0,7 \mathrm{~mL} / \mathrm{kg}$ bo bot badan (13 jam 26 menit). Sementara untuk ratarata jumlah telur ovulasi untuk semua perlakuan berkisar antara 2.255-4.215 butir, di mana jumlah terbanyak didapatkan pada perlakuan Al $10 \mathrm{mg}$ dan ovaprim $0,7 \mathrm{~mL} / \mathrm{kg}$ bobot badan.
Sebaliknya hasil penyuntikan ikan agamysis menggunakan hormon tunggal (satu jenis hormon) yaitu hCG dosis $500 \mathrm{IU}$ maupun Al dosis $10 \mathrm{mg} / \mathrm{kg}$ bobot badan dengan sekali penyuntikan, telur tidak dapat dikeluarkan walaupun telah dilakukan beberapa kali percobaan pengalinan (stripping). Hal ini diduga disebabkan karena telur belum berkembang secara maksimal sehingga folikel telur belum pecah yang menyebabkan ovulasi tidak terjadi. Telur dapat dikeluarkan saat pengalinan apabila telah terjadi 
ovulasi, yaitu keluarnya telur ke rongga ovari atau rongga perut setelah pecahnya folikel oosit. Nagahama (1987) menyatakan bahwa proses ovulasi terdiri atas beberapa tahapan. Pada tahap awal lapisan folikel melepaskan diri dari oosit; pada saat akan terjadi o vulasi, mikrofili pada kedua permukaan tersebut sedikit demi sedikit terpisah. Hal tersebut dimungkinkan dilakukan oleh enzim proteolitik. Dalam setiap perkembangan secara biologi termasuk oosit ikan, perkembangan antara satu fase ke fase yang berikutnya membutuhkan waktu tertentu. Brooks et al. (1997) menambahkan bahwa pada oosit yang telah matang, sitoplasma akan menjadi bening, gelembung minyak bergabung menjadi satu, dan berukuran besar, serta pecahnya vesikel germinal (germinal vesicle breakdown) sehingga terjadi pergeseran inti telur ke tepi. Farastuti (2014) menambahkan bahwa sebelum terjadi ovulasi, sel telur akan mengalami pembesaran. Folikel membentuk semacam benjolan yang semakin membesar sehingga menyebabkan dinding folikel pecah. Pecahnya dinding folikel terjadi pada bagian yang paling lemah (bagian membran) dengan bantuan enzim. Sel-sel teka secara faal bertindak sebagai otot halus yang dapat mendorong oosit keluar dari folikel. Hal ini disebabkan adanya semacam sel otot halus yang pipih dan serat kolagen yang terletak berdekatan dengan basal lamina.

Parameter berikutnya yang diamati yaitu bobot telur dan diameter telur ikan agamysis hasil pemijahan dengan hormon berbeda seperti terlihat pada Tabel 3. Berdasarkan data hasil penyuntikan ikan agamysis menggunakan hormon berbeda didapatkan data rata-rata bobot telur ovulasi berkisar antara 5,93$11,09 \mathrm{~g}$; di mana rata-rata bobot tertinggi pada perlakuan penggunaan hormon Al $10 \mathrm{mg}$ dikombinasikan dengan ovaprim $0,7 \mathrm{~mL} / \mathrm{kg}$ bobot badan. Sementara data rata-rata diameter telur ovulasi berkisar antara 0,88-0,97 mm; di mana rata-rata diameter telur terbesar didapat pada perlakuan kombinasi hCG $500 \mathrm{IU}+$ ovaprim $0,7 \mathrm{~mL} / \mathrm{kg}$ bobot badan.

Diameter telur yang besar pada perlakuan kombinasi hCG $500 \mathrm{IU}+$ ovaprim $0,7 \mathrm{~mL} / \mathrm{kg}$ bobot badan; disebabkan pemberian hCG yang berfungsi untuk menyeragamkan kematangan akhir telur atau mempersiapkan telur yang matang agar siap untuk diovulasikan, serta meningkatkan kepekaan oosit pada pemberian hormon kedua berupa ovaprim (Woynarovich \& Horvath, 1980; Cacot et al., 2002). Proses ini biasanya bisa memperbesar diameter telur, terutama yang tadinya belum matang sehingga rerata diameter telur ovulasinya akan semakin besar.

Data pemijahan selanjutnya yang diamati adalah derajat pembuahan dan penetasan telur seperti terlihat pada Tabel 4. Berdasarkan hasil pengamatan, penyuntikan menggunakan ovaprim $0,7 \mathrm{~mL} / \mathrm{kg}$ bobot badan dengan sekali penyuntikan (tunggal), hormon ini mampu menginduksi terjadinya ovulasi dan pemijahan ikan agamysis (Tabel 2), namun kualitas telur yang dihasilkan kurang baik sehingga diduga menyebabkan rendahnya derajat pembuahan dan daya tetasnya. Hal ini dapat dilihat dari morfologi telur yang tidak sempurna yakni bentuknya pipih, berwarna putih, dan sebagian telur pecah (Gambar 1a), dan hanya sebagian kecil telur yang didapatkan berwarna bening. Pecahnya sebagian telur diduga disebabkan pada proses pengalinan, pengurutan bagian perutnya terasa berat dan sulit dikeluarkan sehingga saat melewati lubang genital telur menjadi pecah. Kondisi ini diduga berpengaruh terhadap rendahnya derajat pembuahan dan penetasan telur pada perlakuan ini.

Penggunaan kombinasi ovaprim dengan Al pada ikan agamysis menghasilkan rata-rata derajat pembuahan sebesar $44,21 \%$ dan merupakan derajat pembuahan telur tertinggi dari semua perlakuan yang diuji. Namun demikian derajat penetasan masih rendah yaitu hanya sebesar 5,86\% Rendahnya derajat penetasan telur diduga berkaitan dengan kualitas telur maupun sperma dari induk yang dihasilkan. Pada perlakuan kombinasi ovaprim dengan Al ini, telur yang berhasil dipijahkan memiliki kondisi yang beragam dengan didapatkannya telur pasca pembuahan yang bentuknya tidak sempurna (berbentuk pipih) namun berwarna bening yang diasumsikan telah terbuahi. Namun pada proses inkubasinya mengalami kegagalan dalam penetasan menyebabkan nilai daya tetasnya menjadi rendah. Menurut Yulfiperius et al. (2003), kualitas telur yang baik dapat dilihat dari derajat tetas telur, abnormalitas larva, dan jumlah larva yang dihasilkan. Rendahnya kualitas telur pada perlakuan ini diduga disebabkan karena pengaruh aromatase inhibitor (Al) yang menghambat proses aromatisasi testosteron menjadi estradiol-17â sebelum telur matang dengan sempurna. Akibatnya adalah proses sintesis vitellogenin terhenti. Estradiol-17â berperan merangsang hati untuk menyintesis vitellogenin (bakal kuning telur) dan dibawa oleh aliran darah menuju gonad dan secara selektif diserap oleh lapisan folikel oosit (Nagahama, 1983; Yaron, 1995; Blazquet et al., 1998). Akibat ketiadaan estradiol-17â terutama sebelum telur berkembang hingga pematangan akhir maka kualitas telur menjadi rendah.

Secara umum, perlakuan penggunaan kombinasi hCG 500 IU dengan ovaprim $0,7 \mathrm{~mL} / \mathrm{kg}$ bobot badan menghasilkan telur yang lebih baik dengan kondisi telur pasca-pengalinan tidak banyak yang pecah dibandingkan semua perlakuan lainnya. Berdasarkan derajat pembuahan nilainya memang sedikit lebih 
Tabel 3. Bobot telur dan perbandingan bobot telur dengan bobot induk serta diameter telur ikan agamysis hasil pemijahan dengan

Table 3. Total eggs weight, total eggs weight per body weight and diameter of agamysis eggs after injectedwith different ovulation hormones

\begin{tabular}{|c|c|c|c|c|}
\hline $\begin{array}{l}\text { Perlakuan } \\
\text { Treatments }\end{array}$ & $\begin{array}{l}\text { Bobot induk } \\
\text { Body weight } \\
\text { (g) }\end{array}$ & $\begin{array}{l}\text { Bobot total telur } \\
\text { Weight of total eggs } \\
\text { (g) }\end{array}$ & $\begin{array}{l}\text { Bobot total telur/ } \\
\text { bobot induk } \\
\text { Weight of total eggs/ } \\
\text { body weight }(\mathbf{g} / \mathbf{g})\end{array}$ & $\begin{array}{l}\text { Rerata diameter } \\
\text { telur } \\
\text { Eggs diameter } \\
(\mathrm{mm})\end{array}$ \\
\hline \multirow{3}{*}{ Ovaprim $0.7 \mathrm{mL.kg-}^{1}$} & 135.00 & 8.5 & 0.06 & $0.88 \pm 0.09$ \\
\hline & 85.50 & 5.5 & 0.06 & $0.93 \pm 0.10$ \\
\hline & 52.21 & 3.8 & 0.07 & $0.90 \pm 0.05$ \\
\hline \multicolumn{2}{|c|}{ Rerata (Average) } & $5.93 \pm 2.38$ & $0.20 \pm 0.07$ & $0.90 \pm 0.08$ \\
\hline \multirow{3}{*}{ hCG 500 IU.kg ${ }^{-1}$} & 50.00 & - & - & - \\
\hline & 90.00 & - & - & - \\
\hline & 84.82 & - & - & - \\
\hline \multicolumn{2}{|c|}{ Rerata (Average) } & - & - & - \\
\hline \multirow{3}{*}{ Al $10 \mathrm{mg} \cdot \mathrm{kg}^{-1}$} & 50.35 & - & - & - \\
\hline & 75.60 & - & - & - \\
\hline & 80.85 & - & - & - \\
\hline \multicolumn{2}{|c|}{ Rerata (Average) } & - & - & - \\
\hline \multirow{2}{*}{$\begin{array}{l}\text { Al } 10 \mathrm{mg}+ \\
\text { ovaprim } 0.7 \mathrm{~mL} . \mathrm{kg}^{1}{ }^{1}\end{array}$} & 89.50 & 7.46 & 0.08 & $0.79 \pm 0.06$ \\
\hline & 200.00 & 14.72 & 0.07 & $0.96 \pm 0.11$ \\
\hline \multicolumn{2}{|c|}{ Rerata (Average) } & $11.09 \pm 5.13$ & $0.16 \pm 0.08$ & $0.88 \pm 0.09$ \\
\hline \multirow{3}{*}{$\begin{array}{l}\text { hCG } 500 \text { IU + } \\
\text { ovaprim } 0.7 \text { mL.kg- }{ }^{1}\end{array}$} & 68.25 & 7.3 & 0.11 & $0.91 \pm 0.08$ \\
\hline & 160.00 & 8.0 & 0.05 & $1.13 \pm 0.12$ \\
\hline & 175.20 & 9.4 & 0.05 & $0.86 \pm 0.09$ \\
\hline \multicolumn{2}{|c|}{ Rerata (Average) } & $8.23 \pm 1.07$ & $0.21 \pm 0.07$ & $0.97 \pm 0.34$ \\
\hline
\end{tabular}

rendah $(23,47 \%$ dibandingkan dengan perlakuan $\mathrm{Al} 10$ $\mathrm{mg}$ yang dikombinasikan dengan Ovaprim $0,7 \mathrm{~mL} / \mathrm{kg}$ bobot badan $(44,21 \%$, namun lebih tinggi dibandingkan perlakuan penyuntikan tunggal ovaprim $0,7 \mathrm{~mL} / \mathrm{kg}$ bobot badan (13,33\%. Tetapi untuk derajat penetasan telurnya, perlakuan ini menghasilkan telur yang mampu menetas dengan persentase yang lebih tinggi dibandingkan semua perlakuan lainnya yakni sebesar $39,31 \% \mathrm{Hal}$ ini diduga berkaitan dengan fungsi hormon hCG sebagai gonadotropin yang langsung bekerja pada tingkat gonad untuk menginduksi pematangan gonad akhir dan ovulasi, di mana pengaruhnya lebih cepat dari pada GnRH meskipun sirkulasinya dalam tubuh ikan pendek (Mylonas et al., 1996). Kinerja hormon hCG diperkuat oleh ovaprim yang juga berperan dalam pematangan oosit tahap akhir. Nandeesha et al. (1990) menyatakan bahwa ovaprim merupakan kombinasi dari salmon Gonadotropin Releasing Hormone analogue ( $\mathrm{s} \mathrm{GnRHa}$ ) dengan antidopamin yang setiap $1 \mathrm{~mL}$ ovaprim mengandung 20 mg sGnRHa (DArg6, Trp7, Leu8, Pro9-NET)-LHRH dan $10 \mathrm{mg}$ antidopamin yang berperan untuk pematangan tahap akhir oosit pada ikan. Pada kegiatan pembenihan, ovaprim digunakan sebagai bahan perangsang pematangan gonad dan pemijahan pada induk. Ovaprim berperan dalam memacu proses ovulasi dan pemijahan pada ikan. GnRHa yang terkandung dalam ovaprim berperan merangsang hipofisa untuk melepaskan gonadotropin (Lam, 1995).

Pada penelitian ini juga dilakukan pengamatan kondisi telur pasca salin untuk melihat kondisi telur yang baik dan dan tidak baik, seperti terlihat pada Gambar 1. 
Tabel 4. Derajat pembuahan dan derajat penetasan telur ikan agamysis hasil pemijahan dengan penyuntikan hormon ovulasi yang berbeda

Table 4. Fertilization and hatching rates of agamysis eggs after injected with different ovulation hormones

\begin{tabular}{|c|c|c|c|}
\hline $\begin{array}{l}\text { Perlakuan } \\
\text { Treatments }\end{array}$ & $\begin{array}{l}\text { Bobot induk } \\
\text { Body weight (g) }\end{array}$ & $\begin{array}{c}\text { Derajat pembuahan } \\
\text { Fertilization rate }(\%)\end{array}$ & $\begin{array}{c}\text { Daya tetas } \\
\text { Hatching rate }(\%)\end{array}$ \\
\hline \multirow{3}{*}{ Ovaprim 0.7 mL.kg- ${ }^{1}$} & 135.00 & 10 & 0 \\
\hline & 85.50 & 20 & 3 \\
\hline & 52.21 & 10 & 0 \\
\hline \multicolumn{2}{|c|}{ Rerata (Average) } & $13.33 \pm 5.77$ & $1.00 \pm 1.73$ \\
\hline \multirow{3}{*}{ hCG 500 IU.kg ${ }^{-1}$} & 50.00 & - & - \\
\hline & 90.00 & - & - \\
\hline & 84.82 & - & - \\
\hline \multirow{4}{*}{ Al $10 \mathrm{mg} \cdot \mathrm{kg}^{-1}$} & 50.35 & - & - \\
\hline & 75.60 & - & - \\
\hline & 80.85 & - & - \\
\hline & 89.50 & 21.74 & 3.82 \\
\hline \multirow{2}{*}{$\begin{array}{l}\text { Al } 10 \mathrm{mg}+ \\
\text { ovaprim } 0.7 \mathrm{~mL} . \mathrm{kg}^{1}{ }^{1}\end{array}$} & 200.00 & 66.67 & 7.89 \\
\hline & 55.20 & - & - \\
\hline \multicolumn{2}{|c|}{ Rerata (Average) } & $44.21 \pm 31.77$ & $5.86 \pm 2.88$ \\
\hline \multirow{3}{*}{$\begin{array}{l}\text { hCG } 500 \text { IU + } \\
\text { ovaprim } 0.7 \text { mL.kg- }{ }^{1}\end{array}$} & 68.25 & 34.70 & 38.00 \\
\hline & 160.00 & 30.00 & 32.50 \\
\hline & 175.20 & 5.71 & 50.44 \\
\hline \multicolumn{2}{|c|}{ Rerata (Average) } & $23.47 \pm 15.56$ & $39.31 \pm 9.19$ \\
\hline
\end{tabular}

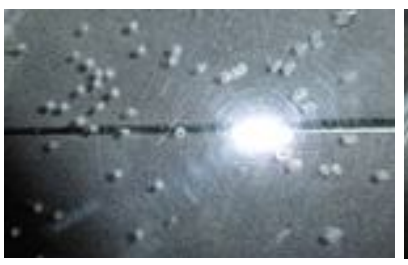

(a)

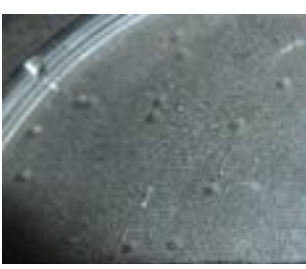

(b)

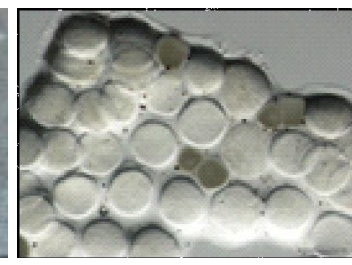

(c)

Gambar 1. Kondisi telur agamysis pascasalin: (a) kondisi kurang baik, (b) relatif baik, dan (c) telur pada perbesaran $40 x$ dengan skala bar $1 \mathrm{~mm}$.

Figure 1. Agamysis eggs post-stripping: (a) unfavorable conditions, (b) relatively good, and (c) egg with magnification 40x and $1 \mathrm{~mm}$ bar scale.

Kondisi telur pasca salin pada penyuntikan menggunakan kombinasi hCG dan ovaprim terlihat telur berwarna bening dan bentuknya bulat utuh (Gambar 1b). Hal ini disebabkan karena pada saat stripping kondisi pengeluaran telurnya lebih mudah dan lancar. Akibatnya telur tidak banyak yang pecah karena gesekan dengan lubang genital seperti pada penyuntikan dengan ovaprim saja. 


\section{KESIMPULAN}

Penggunaan kombinasi hormon human chorionic gonadotropin dosis $500 \mathrm{lU} / \mathrm{kg}$ dan LHRHa yang ditambahkan antidopamin (ovaprim) dosis $0,7 \mathrm{~mL} / \mathrm{kg}$ dalam menginduksi ovulasi dan pemijahan ikan agamysis memberikan respons pemijahan terbaik. Penggunaan kombinasi hormon hCG dan ovaprim efektif menstimulasi proses ovulasi telur sehingga dapat menjadi acuan untuk peningkatan produksi larva ikan agamysis dalam pemijahan buatan.

\section{UCAPAN TERIMA KASIH}

Penelitian ini merupakan kegiatan yang didanai oleh DIPA-APBN Tahun 2015. Terima kasih kami ucapkan kepada para teknisi Laboratorium Basah Bioreproduksi Balai Penelitian dan Pengembangan Budidaya Ikan Hias (BPPBIH) Depok yang telah membantu pelaksanaan penelitian ini (Angga G.; Dinar P., Hasan, dan Rona D.A.) serta tim peneliti ikan agamysis atas kerja samanya.

\section{DAFTAR ACUAN}

Adi, C.H. (1999). Pengaruh kombinasi hCG dan ekstrak kelenjar hipofisa ikan mas terhadap proses ovulasi ikan baung (Mystus nemurus C.V). Tesis. Sekolah Pascasarjana. Intitut Pertanian Bogor.55 hal.

Arfah, H., Maftucha, L., \& Carman, O. (2006). Pemijahan secara buatan pada ikan gurame (Osphronemus gouramy Lac.) dengan penyuntikan ovaprim. Jurnal Akuakultur Indonesia, 5(2), 103-112.

Blazquet, M., Bosma, P.T., Fraser, E.J., Van Look, K.J.W., \& Trudeau, V.L. (1998). Fish as model for the neuroendocrine regulation of reproduction and growth. Comparative Biochemistryand Physiology Part C, 199, 345-364.

Brooks, S., Tyler, C.R., \& Sumpter, J.P. (1997). Egg quality in fish: what makes a good egg?. Reviews in Fish Biology and Fisheries, 7, 387-416.

Cacot, P., Legendre, M., Dan, T.Q., Hung, L.T., Liem, P.T., Mariojouls, C., \& Lazard, J. (2002). Induced ovulation of Pangasius bocourti (Sauvage, 1880) with a progressive hCG treatment. Aquaculture, 213,199-206.

Effendie, M.I. (1997). Biologi perikanan. Yogyakarta: Yayasan Pustaka Nusatama, $163 \mathrm{hlm}$.

Farastuti, E.R. (2014). Induksi maturasi gonad, ovulasi dan pemijahan pada ikan Torsoro (Tor soro) menggunakan kombinasi hormon. Tesis. Sekolah Pascasarjana. Intitut Pertanian Bogor. Bogor, 68 hlm.

Hakim, F.N. (2010). Efektivitas kombinasi aromatase inhibitor dan ovaprim dalam merangsang pemijahan ikan Sumatera (Puntius tetrazona). Skripsi. Program
Studi Teknologi dan Manajemen Akuakultur, Departemen Budidaya Perairan Fakultas Perikanan dan Ilmu Kelautan. Institut Pertanian Bogor. Bogor, $48 \mathrm{hlm}$.

Iswanto, B., Imron, Suprapto, R., Marnis, H., \& Ridzwan, N.S. (2014). Evaluasi performa pertumbuhan ikan lele Afrika (Clarias gariepinus) G2 hasil seleksi pada beberapa sistem budidaya. Dalam Sugama, K., Kusnendar, E., Rachmansyah, Giri, N.A., Yuhana, M., Kristanto, A.H., Imron, Radiarta, I N., \& Dewi, R.R.S.P.S. (Eds.), Forum Inovasi Teknologi Akuakultur 2014. Pusat Penelitian dan Pengembangan Perikanan Budidaya, Badan Litbang Kelautan dan Perikanan. Jakarta, hlm. 809-816.

Keys, S.J. \& Crocos, P.J. (2006). Domestication, growth and reproductive performance of wild, pond and tank-reared brown tiger shrimp (Penaeus esculentusi). Aquaculture, 257, 232-240.

Lam, T.J. (1995). Induced spawning in fish. Proceedings for Workshop Held in Tungkang Marine Laboratory. Taiwan. April 22-24 1995. Reproduction in Culture of Milkfish, hlm. 14-65.

Luna, Susan, M., Reyes, \& Rodolfo, B. (2014). Agamyxis pectinifrons (Cope, 1870) Whitebarred catfish. http:/ /www.fishbase.org/summary/12104, diakses tanggal 6 Maret 2014.

Legendre, M., Satyani, D., Subandiyah, S., Sudarto, Pouyaud, L., Baras, E., \& Slembrouck, J. (2012). Biology and culture of the clown loach (Chromobotia macrancanthus Cypriniformes, Cobitidae): 1-Hormonal induced breeding, unusual latency response and egg production in two populations from Sumatra and Borneo Islands. Aquatic Living Resources, 25, 95-108.

Mahdaliana. (2014). Induksi ovulasi dan pemijahan semialami pada ikan patin (Pangasianodon hypophthalmus) menggunakan kombinasi hormon aromatase inhibitor dan oksitosin. Tesis. Sekolah Pascasarjana Institut Pertanian Bogor. Bogor, $30 \mathrm{hlm}$.

Mylonas, C.C., Magnus, Y., Gissis, A., Klebano, Y., \& Zohar, Y. (1996). Application of controlled-release $\mathrm{GnRH}$-deliveried system in commercial production of white bass xstripped bass hybrid (Sunshine bass) using captive broodstocks. Aquaculture, 40, 265-280.

Mylonas, C.C., Fostier, A., \& Zanuy, S. (2010). Broodstock management and hormonal manipulations of fish reproduction. General and Comparative Endocrinology, 165, 516-534.

Nagahama, Y. (1983). The functional morphology of teleost gonads. Fish Physiology, 9, 223-275. 
Nagahama, Y. (1987). 17á, 20â-dyhidroxy-4-pregnen3-one: a teleost maturation inducing hormone. Develop. Growth and Differ., 29(1), 1-12.

Nandeesha, M.C., Rao, K.G., Jayanna, R.N., Parker, N.C., Varghese, T.J., Keshavanath, P., \& Shetty, H.P. (1990). Induced spawning of Indian major carps through single application of Ovaprim-C. In Hirano, R., \& Hanyu, I. (Eds.), The Second Asian Fisheries Forum. Asian Fisheries Society, Manila. Philiphines, p. 581-585.

Sukendi, Putra, R.M., \& Yurisman. (2010). Pengaruh kombinasi penyuntikan ovaprim dan Prostaglandin-F2á (PGF2á) terhadap daya rangsang ovulasi dan kualitas telur ikan motan (Thynnicthys thynnoides Blkr). Berkala Perikanan Terubuk, 38(2), 95-103.

Sumantri, D. (2006). Efektivitas ovaprim dan aromatase inhibitor dalam mempercepat pemijahan pada ikan leledumbo Clarias sp. Skripsi. Departemen Budidaya
Perairan, Fakultas Perikanan dan IImu Kelautan, Institut Pertanian Bogor. Bogor, $37 \mathrm{hlm}$.

Woynarovich, E. \& Horvath, L. (1980). The artificial propagation of warm water finfishes-amanual for extension. FAO Fish. Tech. Pap., 201, 183 pp.

Yanong, R.P.E., Martinez, C., \& Watson, C.A. (2015). FA161: Use of ovaprim in ornamental fish aquaculture. Fisheries and Aquatic Sciences Departement, School of Forest Resources and Conservation, Tropical Aquaculture Laboratory. UF/IFAS Extension. University of Florida, p. 1-7.

Yaron, Z. (1995). Endocrine control of gametogenesis and spawning induction in the carp. Aquaculture, 129, 49-73.

Yulfiperius, Mokoginta,I., \& Jusadi, D. (2003). Pengaruh kadar vitamin E dalam pakan terhadap kualitas telur ikan patin (Pangasius hypophthalmus). Jurnal Iktiologi Indonesia, 3(1), 11-18. 